\title{
THE USE OF NITINOL RODS IN SURGICAL TREATMENT OF DEGENERATIVE SCOLIOSIS. 2.5-YEAR FOLLOW-UP
}

\author{
USO DE HASTES DE NITINOL NO TRATAMENTO CIRÚRGICO DE ESCOLIOSE DEGENERATIVA. \\ ACOMPANHAMENTO DE DOIS ANOS E MEIO
}

\author{
USO DE VARILLAS DE NITINOL EN EL TRATAMIENTO QUIRÚRGICO DE ESCOLIOSIS \\ DEGENERATIVA.ACOMPANNAMIENTO DE DOS AÑOS Y MEDIO.
}

Natalia Sergeyevna Morozova¹, Dmitriy Aleksandrovich Kolbovsky ${ }^{1}$, Arkadiy Ivanovich Kazmin ${ }^{1}$, Sergey Vasilievich Kolesov ${ }^{1}$

1. Federal Scientific Research Institute of Traumatology and Orthopedics named after N.N. Priorov, 10 Priorov Street, 127299, Moscow, Russia.

\begin{abstract}
Objectives: To compare the outcomes of surgical treatment with lumbar fixation using nitinol rods without fusion and with standard lumbar fixation with titanium rods and interbody fusion. Methods: Treatment results of 70 patients with degenerative lumbar scoliosis aged 40 to 82 were analyzed. In all cases pedicle screws and nitinol rods with a diameter of $5.5 \mathrm{~mm}$ were used. Thirty patients underwent fixation at L1-S1 and 40 patients underwent fixation at L1-L5. Spinal fusion was not performed. All patients had radiography, CT and MRI performed. The results were assessed according to the Oswestry scale, SRS 22, SF 36 and VAS. The minimum follow-up period for all patients was 2.5 years. For the control group, consisting of 72 patients, pedicle fixation with titanium rods and interbody fusion in the lumbosacral region were performed. Results: The average level of deformity correction equaled $25^{\circ}\left(10^{\circ}-38^{\circ}\right)$. The analysis of X-ray and CT-scans revealed a single patient with implant instability, two patients with bone resorption around the screws and one patient with rod fractures. Functional radiography 2.5 years after surgery showed an average mobility of the lumbar spine of $21^{\circ}\left(15^{\circ}-30^{\circ}\right)$. There were no problems at the adjacent levels. Conclusions: The use of nitinol rods in spinal deformity surgery is promising. This technology is an alternative to rigid fixation. Continued gathering of clinical data and its further evaluation is necessary.
\end{abstract}

Keywords: Scoliosis; Internal fixators; Orthopedic fixation devices.

\section{RESUMO}

Objetivos: Comparar os resultados de tratamento cirúrgico com fixação lombar usando hastes de nitinol sem artrodese e com fixação lombar padrão com hastes de titânio e fusão intersomática. Métodos: Foram analisados os resultados do tratamento em 70 pacientes com escoliose lombar degenerativa com idades entre 40 e 82 anos. Em todos os casos, foram usados parafusos pediculares e hastes de nitinol com diâmetro de $5,5 \mathrm{~mm}$. Trinta pacientes foram submetidos à fixação em L1-S1 e 40 pacientes tiveram fixação em L1-L5. Não foi realizada artrodese da coluna. Todos os pacientes fizeram radiografias, TC e RM. Os resultados foram avaliados de acordo com a escala de Oswestry, com o SRS 22, o SF 36 e EVA. O período mínimo de acompanhamento para todos os pacientes foi de 2,5 anos. No grupo controle, com 72 pacientes, realizou-se a fixação do pedículo com hastes de titânio e fusão intersomática na região lombossacral. Resultados: O nível médio de correção da deformidade correspondeu a $25^{\circ}\left(10^{\circ}-38^{\circ}\right)$. A análise das radiografias e das TC revelou um único paciente com instabilidade, dois pacientes com reabsorção óssea ao redor dos parafusos e um paciente apresentou fraturas da haste. A radiografia funcional 2,5 anos após a cirurgia mostrou mobilidade média da coluna lombar de $21^{\circ}\left(15^{\circ}-30^{\circ}\right)$. Não foram encontrados problemas nos níveis adjacentes. Conclusões: O uso de hastes de nitinol na cirurgia de deformidades da coluna é promissor. Essa tecnologia é uma alternativa à fixação rígida. É preciso manter a coleta continuada de dados clínicos e sua posterior avaliação.

Descritores: Escoliose; Fixadores internos. Dispositivos de fixação ortopédica.

\section{RESUMEN}

Objetivos: Comparar los resultados de tratamiento quirúrgico con fijación lumbar usando varillas de nitinol sin artrodesis y con fijación lumbar estándar con varillas de titanio y fusión intersomática. Métodos: Fueron analizados los resultados del tratamiento en 70 pacientes con escoliosis lumbar degenerativa con edades entre 40 y 82 años. En todos los casos, fueron usados tornillos pediculares y varillas de nitinol con diámetro de 5,5 mm. Treinta pacientes fueron sometidos a fijación en L1-S1 y 40 pacientes tuvieron fijación en L1-L5. No fue realizada artrodesis de la columna. Todos los pacientes hicieron radiografías, TC y RM. Los resultados fueron evaluados de acuerdo con la escala de Oswestry, con SRS 22, SF 36 y EVA. El período mínimo de acompañamiento para todos los pacientes fue de 2,5 años. En el grupo control, con 72 pacientes, se realizó la fijación del pedículo con varillas de titanio y fusión intersomática en la región lumbosacra. Resultados: El nivel medio de corrección de la deformidad correspondió a $25^{\circ}\left(10^{\circ}-38^{\circ}\right)$. El análisis de las radiografías y de las TC reveló un único paciente con inestabilidad, dos pacientes con reabsorción ósea alrededor de los tornillos y un paciente presentó fracturas de la varilla. La radiografía funcional 2,5 años después de la cirugía mostró movilidad media de la columna lumbar de $21^{\circ}\left(15^{\circ}-30^{\circ}\right)$. No fueron encontrados problemas en los niveles adyacentes. Conclusiones: El uso de varillas de nitinol en la cirugía de deformidades de la columna es promisor. Esa tecnología es una alternativa para la fijación rígida. Es preciso mantener la colecta continuada de datos clínicos y su posterior evaluación.

Descriptores: Escoliosis; Fijadores internos; Dispositivos de fijación ortopédica.

Study conducted at the Department of Spinal Pathology of the Federal Scientific Research Institute of Traumatology and Orthopedics named after N. N. Priorov, Moscow, Russia.

Correspondence: Russian Federation, Moscow Region, Krasnogorsk, 5 Kosmonavtov Boulevard, apt. 589, 143408 morozcito@gmail.com 
Degenerative scoliosis is a disease that is more common among people in the later stages of life. Its clinical course involves severe pain, radicular damage and loss of sagittal and frontal balance of the body. Due to lateral listhesis of the lumbar vertebrae, spinal stenosis develops at multiple levels. Intermittent claudication may also develop in patients. In addition, patients may also have osteoporosis, which exacerbates the progression and creates treatment difficulties. Conservative treatment is not very effective, so the method of choice is surgical treatment. During surgical treatment, a multilevel transpedicular fixation from the lower thoracic or upper lumbar to the L5 or $\mathrm{S} 1$ vertebrae is carried out. When performing fixation below $L 5$, it is recommended to combine sacro-pelvic fixation with an interbody fusion at L5-S1 and L4-L5. ${ }^{1-5}$ When conducting a standard rigid fixation, a titanium rod of $5.5 \mathrm{~mm}$ or $6 \mathrm{~mm}$ in diameter is used. As a result of the fixation and deformity correction, bending decreases, and sagittal and frontal balance improve. Decompression of the spinal canal and the nerve roots is also performed. In most cases, surgery improves the patients' quality of life. However, when performing surgery for spinal deformity in adults, the percentage of complications can be as high as 53\%, with "serious" complications as high as $8.4 \%$. The most common complications of degenerative scoliosis surgery are proximal junctional kyphosis (PJK) (28\%), infection (46\%), and pseudoathrosis (10\%). According to the literature, $44 \%$ of patients will require revision surgery within 5 years. ${ }^{6,7}$ Furthermore, rigid fixation of the lumbar spine significantly violates its biomechanics, especially if the fixation area includes the sacrum. Because of the rigidity of the titanium rods in the absence of fusion, the implants become loose in the bone, hence the search for new solutions in spinal fixation.

Nitinol, a nickel (55\%) and titanium (45\%) alloy, is a unique material with shape memory. According to its physical characteristics, its plasticity is eight times greater than titanium. The crystalline structure of nitinol is more durable and has better resistance to cyclic loads. However, there are no analytical articles devoted to its use in the treatment of spinal deformity. Our early surgical experience of using nitinol rods should prove quite informative for spinal surgeons. The main purpose of our work was to determine the effectiveness of the use of nitinol rods for deformity correction and fixation of the lumbar spine region in degenerative scoliosis patients.

Fixation of the lumbar spine was performed without fusion. We then sought to determine whether the motion of the fixed segment is preserved; how common bone resorption around the implant is; what kinds of complications are possible and how often they occur; and how the results of treatment differ between the control group with standard fixation and the group with the use of nitinol.

\section{MATERIALS AND METHODS}

Investigation approved by the Roszdravnadzor Ethics Committee (approval number: 18194533). The study was conducted using two groups of patients, all of whom signed an informed consent form. The first group included 70 patients with degenerative lumbar scoliosis, who were operated on using $5.5 \mathrm{~mm}$ rods made of nitinol and standard polyaxial pedicle screws without using bone grafts. The second group included 72 patients with the same condition, who were operated on according to the standard procedures. Rigid titanium rods of $5.5 \mathrm{~mm}$ in diameter and polyaxial pedicle screws were used. When the level of fixation involved the S1 vertebra, an additional L5-S1 interbody fusion was carried out.

All procedures were carried out between 2011 and 2014 by two surgeons. The first group consisted of patients aged 40 to 82 years. The patients in the second group were aged 39 to 84 years. In the first group, the gender ratio was 37 female to 33 male patients, while in the second group, there were 42 female and 30 male patients. All patients complained of pain in the lower back, leg pain, and radicular disorders (reduced sensitivity). Some patients had symptoms of myelogenous intermittent claudication (15 patients in group one and 18 in group two). All patients were examined using plain radiography, CT and MRI. All patients were operated on at the Department of Spinal Pathology, CITO named after N.N. Priorov (Moscow, Russia).

\section{Clinical evaluation}

Before and after surgery, all patients were tested using several questionnaires: VAS, Oswestry, SF36 and SRS22. The testing was conducted at 3 months, 6 months, 1.5 years and 2.5 years after surgery.

\section{Radiographic picture}

In the evaluation of the radiographs, the Cobb angle of deformation and lumbar lordosis were measured, and the global sagittal and frontal balances before and after surgery were evaluated. Functional radiographs were performed 2.5 years after surgery to evaluate the range of motion of the lumbar spine. The Cobb angle was evaluated using radiographs in flexion and extension of the top and bottom vertebrae involved in the fixation. In addition, the range of flexion-extension movements in each fixed segment was measured using the Cobb angle technique. Two and a half years after surgery, CT studies were performed on all patients, to evaluated the presence of bone resorption around the pedicle screws.

\section{Surgical technique}

In the first group, the standard posterior approach was carried out. When the pedicle screws were inserted, the intervertebral joints were kept intact. After installing the standard polyaxial screws, decompression of the spinal canal by hemi- and full laminectomy was performed. Next, two nitinol rods, precooled to the activation temperature, were installed. The rods were modeled according to the degree of lumbar lordosis $\left(35^{\circ}-40^{\circ}\right)$. Spinal fusion and bone grafting were not carried out. Fixation was performed between levels L1 and S1 in 30 patients, and between L1 and L5 in 40 patients. In the second group, the standard posterior approach was also carried out. Polyaxial pedicle screws were installed. The spinal canal was decompressed by hemi- and full laminectomy. When involving the S1 vertebra, the interbody fusion was carried out at L5-S1 by the means of posterior lumbar interbody fusion (PLIF) or transforaminal lumbar interbody fusion (TLIF) using cages. The rods were then installed. Additionally, bone grafting was performed on transverse processes and posterior elements of the vertebrae using autografts. Fixation from $\mathrm{L} 1$ to $\mathrm{S} 1$ was performed in 30 patients, and from L1 to L5 in 42 patients.

\section{Statistical analysis}

For statistical analysis IBM SPSS Statistics version 23.0.0.0 was used.

\section{RESULTS}

During the analysis of the treatment results, the following data was obtained. The degree of curvature correction of the lumbar spine was similar in both groups. Before the operation, the angle of scoliotic curvature was an average of $35^{\circ}\left( \pm 5^{\circ}\right)$ in group one, and an average of $40^{\circ}\left( \pm 5^{\circ}\right)$ in group two. After the operation, this averaged was $14^{\circ}\left( \pm 5^{\circ}\right)$ in group 1 , and $13^{\circ}\left( \pm 5^{\circ}\right)$ in group 2 . Analyzing the sagittal profile of the deformation before surgery, lumbar lordosis was an average of $5^{\circ}\left( \pm 3^{\circ}\right)$ in group 1 , and an average of $7^{\circ}\left( \pm 3^{\circ}\right)$ in group 2. Lumbar lordosis after surgery was $25^{\circ}\left( \pm 3^{\circ}\right)$ in group 1 , and $32^{\circ}\left( \pm 3^{\circ}\right)$ in group 2. Global frontal balance in group 1 was $3 \mathrm{~cm}( \pm 1 \mathrm{~cm})$ before surgery, and $0.5 \mathrm{~cm}( \pm 1 \mathrm{~cm})$ after surgery, while in group 2 it was $3.5 \mathrm{~cm}( \pm 1 \mathrm{~cm})$ before surgery and $0.3 \mathrm{~cm}$ $( \pm 1 \mathrm{~cm})$ after surgery. The global sagittal balance in group 1 was $2.5 \mathrm{~cm}( \pm 1 \mathrm{~cm})$ before surgery, and $+0.2 \mathrm{~cm}( \pm 1 \mathrm{~cm})$ after surgery, while in group 2 it was $2.7 \mathrm{~cm}( \pm 1 \mathrm{~cm})$ before surgery, and $0.3 \mathrm{~cm}( \pm 1 \mathrm{~cm})$ after surgery. During the assessment of mobility of the lumbar spine region, the radiographs in flexion and extension showed the following results: lumbar motion from L1 to S1 averaged $50^{\circ}\left( \pm 3^{\circ}\right)$ in group 1 , and $58^{\circ}\left( \pm 3^{\circ}\right)$ in group 2. After surgery, motion of the lumbar spine region fixed by nitinol rods averaged $21^{\circ}( \pm$ $3^{\circ}$ ) in group 1 , while in the second group, no motion was observed in the fixed segments. In the functional radiographs, motion of $11^{\circ}$ $\left( \pm 1^{\circ}\right)$ was observed in segment L5-S1 only if it was not included in the zone of fixation. 
When analyzing the duration of the surgery in the first group, the average operating time was 185 minutes ( $\pm 15 \mathrm{~min})$. In the second group it was more than 243 minutes ( $\pm 15 \mathrm{~min}$ ). This difference in time was due to time-consuming interbody fusion. The average amount of blood lost in group 1 was $400 \mathrm{cc}$. ( $\pm 50 \mathrm{cc}$.), and in group 2, $700 \mathrm{cc}$. ( $\pm 50 \mathrm{cc}$.). This difference is due to interbody fusion using the PLIF and TLIF methods, as well as decortication of posterior elements while performing posterior fusion. While carrying out these phases of the operation, an additional loss of blood occurred, usually from the epidural veins and the bone.

The results of the surveys according to different questionnaires were as follows. In group 1, the SF36 physical health questionnaire before surgery produced on average 32.4 points and after surgery, 63.5 points $(p<0.05)$. The mental health questionnaire before surgery produced an average of 42.5 points, and after surgery, 76.3 points $(p<0.05)$. (Figure 1) SRS 22 in the first group showed the following results: (Table 1) Oswestry questionnaire data: 64.6 points before surgery and 17.8 ( $p<0.05$ ) after surgery. (Figure 2) Average VAS before surgery was 9.3 , while after surgery, average VAS was 2.4 ( $p<0.05)$. (Figure 3, 4, 5 e 6)

In group 2, the average SF 36 index of physical health before surgery was 33.4 points, while after surgery, the average SF was 58.5 points $(p<0.05)$. The average score on the mental health index before surgery was 41.4 points, while the average after surgery was 72.2 points $(p<0.05)$. The results of the SRS 22 index in the second group were as follows. (Table 1). Oswestry questionnaire data: 64.0 points before surgery, 17.7 points $(p<0.05)$ after surgery. Preoperative VAS score: average of 9.4 before surgery, $2.1(p<0.05)$ after surgery.

It is clear that according to various questionnaires, the outcomes 2.5 years after surgery are better in group 1 where nitinol rods were used. Analyzing complications, the following data was obtained. In the first group of patients, 2.5 years after surgery the following complications were recorded: implant instability -1 , bone resorption around the screws -2 , rod fractures -1 . Revision surgery was required in all cases. Two patients had infection-related complications (one superficial and one deep suppuration). In both cases, open wound drainage was used, followed by secondary suturing. Removal of the instrumentation was not required. In the second group of patients, with rigid fixation, the number of complications

Table 1. Comparison of preoperative and postoperative (2.5 years) SRS-22 scores for each of the four categories.

\begin{tabular}{c|c|c|c}
\hline Group 1 & $\begin{array}{c}\text { Preoperative score } \\
\text { (mean) }\end{array}$ & $\begin{array}{c}\text { Postoperative score at 2.5 } \\
\text { years (mean) }\end{array}$ & $\mathbf{P}$ \\
\hline Pain & 2.4 & 4.2 & $<0.05$ \\
\hline Self-image & 2 & 5 & $<0.05$ \\
\hline Function & 2.2 & 4.6 & $<0.05$ \\
\hline Mental heals & 3 & 4.4 & $<0.05$ \\
\hline Group 2 & $\begin{array}{c}\text { Preoperative score } \\
\text { (mean) }\end{array}$ & $\begin{array}{c}\text { Postoperative score } \\
\text { at 2.5 years (mean) }\end{array}$ & $\mathbf{P}$ \\
\hline Pain & 2.4 & 3.8 & $<0.05$ \\
\hline Self-image & 2.2 & 4.6 & $<0.05$ \\
\hline Function & 2.2 & 4 & $<0.05$ \\
\hline Mental heals & 3 & 4.4 & $<0.05$ \\
\hline
\end{tabular}

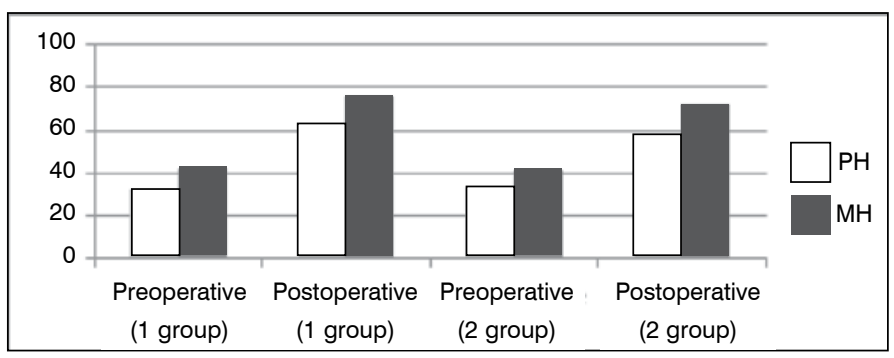

Figure 1. Pre-op and post-op SF-36 scores in groups 1 and 2.

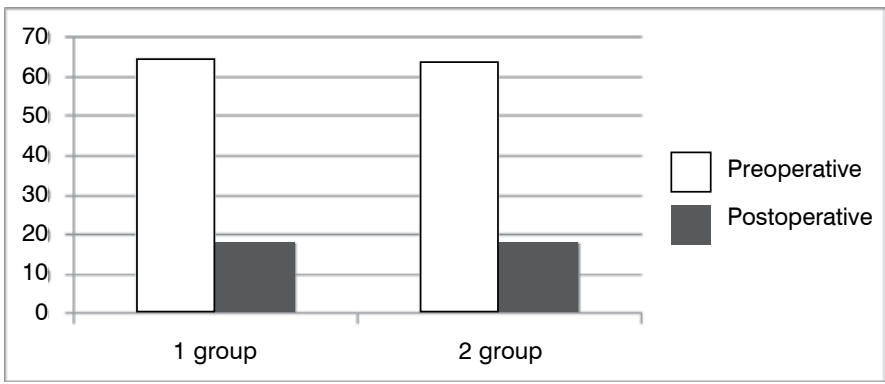

Figure 2. Pre-op and post-op Oswestry scores in groups 1 and 2.

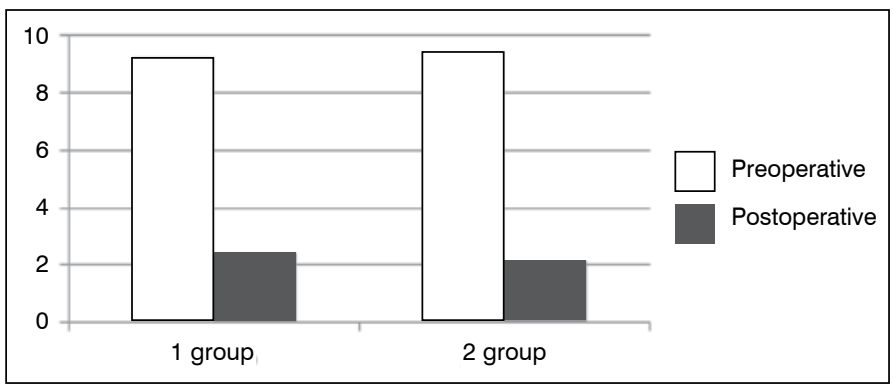

Figure 3. Pre-op and post-op VAS scores in groups 1 and 2.

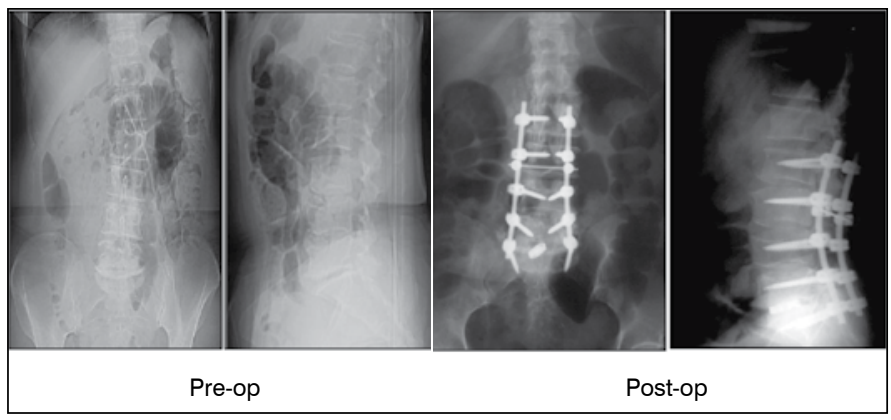

Figure 4. Patient 57 years. Ds: Degenerative scoliosis. X-rays before and after surgery.

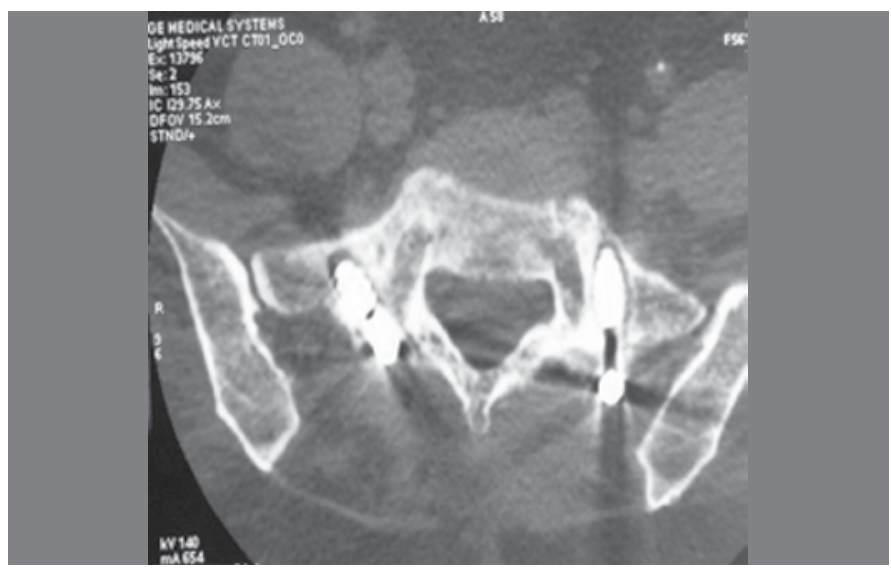

Figure 5. Patient 57 years. Ds: Degenerative scoliosis. CT scans - one year after surgery. Arrows - resorption around the screws.

was higher. Suppuration was observed in one patient. Ppen wound drainage was used, followed by secondary suturing. Pseudarthrosis was found in 6 patients. Proximal kyphosis was found in 2 patients, and rod fractures in 3 patients. Revision surgery was performed in 12 patients. Thus, in the group in which nitinol rods were used, the results 2.5 years after treatment were better in terms of the basic parameters: blood loss, operative time, number of complications, and quality of life assessment according to various questionnaires. 


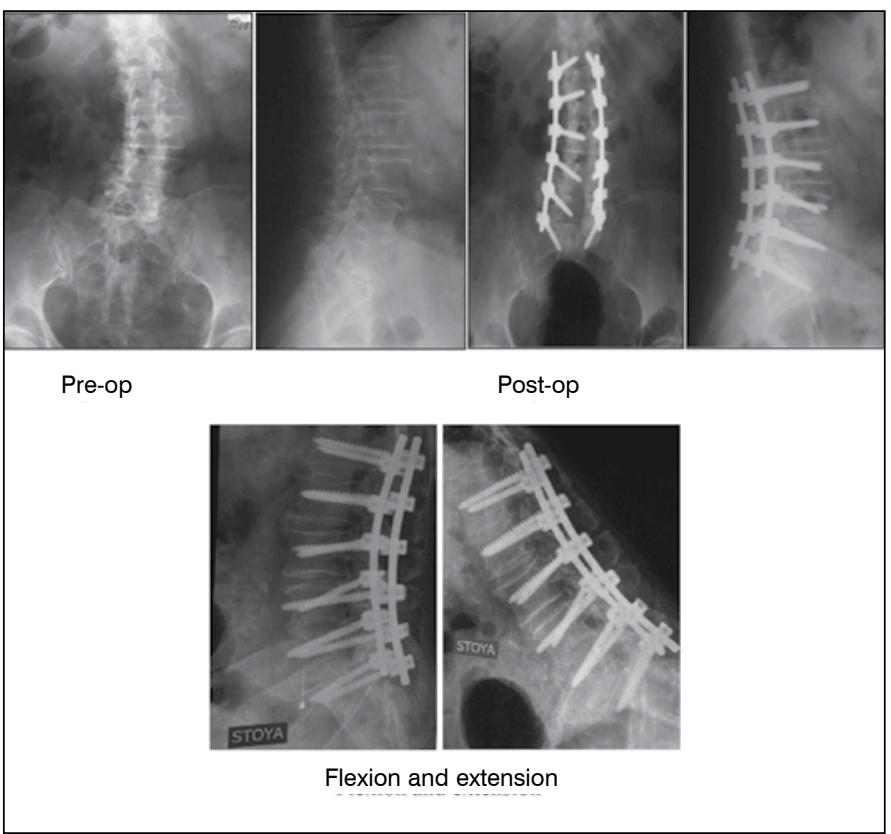

Figure 6. Patient 75 years. Ds: Degenerative scoliosis. X-rays before surgery and after surgery with flexion and extension.

\section{DISCUSSION}

Rigid multilevel lumbosacral fixation of the spine combined with decompression of the spinal canal has been the "gold standard" in the treatment of degenerative scoliosis. When the sacrum is involved in the fixation region, interbody fusion of the L5-S1 segment and, in some cases, the L4-L5 segment must be performed.

During the correction and fixation of the deformation, modeling of lumbar lordosis and the establishment of optimal sagittal and frontal balances of the spine are necessary. Particular attention is paid to a high-quality posterior fusion, as a deficiency in the technique often leads to loosening of implants and pseudarthrosis. Osteoporosis, which is often observed in this category of patients, is associated with serious problems. ${ }^{8}$ In defective bone implants, the risk of instability increases significantly. To enhance the stability of the screws, bone cement is used in combination with fenestrated screws.

A high percentage of complications are observed in the proximal part of the instrumentation (up to $30 \%$ ). The vertebrae in the zone of transition from the fixed part of the spine to the unfixed segments are subject to higher levels of strain, which leads to the formation of proximal kyphosis (PJK) due to compression fractures, dislocations, or subluxation of the vertebrae. This phenomenon is addressed mainly by extending the length of fixation, which increases the area of spine immobility.

Nitinol is a unique material that combines optimal rigidity with plasticity. However, there is no published data on its use in the final fixation of spinal deformities. Wang et al. ${ }^{9}$ used rods with shape memory (nitinol rods) as a fixation method at an intermediate stage of scoliotic curve correction. This technique was used in 38 patients with scoliosis. During the surgical correction of the scoliotic arc, rods made of nitinol were initially cooled to the activation temperature. They were fixed to the concave side of the scoliotic arc, then the strain was adjusted. The shape memory rod was then replaced with a rigid rod. Di Silvestre et al. ${ }^{10}$ advocate fixation of degenerative de novo lumbar scoliosis using the dynamic Dynesys system.

Our study is based on the fixation of degenerative lumbar scoliosis using shape memory rods as a final fixation method. Our relatively small group of patients with degenerative scoliosis of the lumbar spine showed good results in the analysis of treatment results 2.5 years after surgery.

The questionnaires showed a slightly higher evaluation of the treatment results using nitinol rods compared to the control group. However, it should be noted that during the treatment of deformations using nitinol rods, the correction of the spinal profile is less effective due to their plasticity, especially in the treatment of lumbar lordosis. At the same time, a small amount of movement is observed in each fixed segment, which relieves the pressure on the pedicle screws and preserves the non-fixed segments above and below from overload and related problems. In our opinion, the use of nitinol rods in spinal deformity surgery can simplify the surgical technique, as there is no need to perform bone fusion in the lumbosacral region. This minimizes surgical trauma and blood loss.

\section{CONCLUSIONS}

The use of nitinol rods without fusion in the surgical treatment of degenerative scoliosis showed good results 2.5 years after surgery. Their use preserves motion in the fixed spine, thereby reducing the number of complications commonly seen in rigid fixation. However, we must continue to gather clinical data and study the long-term results.

All authors declare no potential conflict of interest concerning this article.

CONTRIBUTIONS OF THE AUTHORS: Each author made a significant individual contribution to the development of the manuscript. The biggest contribution was from NSM, she wrote the article, operated on most of the patients and accumulated and analyzed the needed data through the 2.5 years. SVK is the head of the department, he has directed the research, edited the text, made valuabe suggestions throughout the process and also operated on most of the patients. DAK and AIK have helped with the research process, surgery, data collection and suggestions.

\section{REFERENCES}

1. Kostuik JP. Adult scoliosis. In: Frymoyer J, editor. The Adult Spine: Principles and Practice. New York: Raven Press; 1991. p. 1127-39.

2. Kostuik JP, Israel J, Hall JE. Scoliosis surgery in adults. Clin Orthop Relat Res 1973;(93):225-34

3. Kostuik JP, Worden HR, Salo P. Long term functional outcome following surgery for adult scoliosis. In: American Orthopaedic Association June meeting; 1990; Boston, MA

4. Schwab FJ, Smith VA, Biserni M, Gamez L, Farcy JP, Pagala M. Adult scoliosis: a quantitative radiographic and clinical analysis. Spine (Phila Pa 1976). 2002;27(4):387-92.

5. Bridwell KH, Edwards CC 2nd, Lenke LG. The pros and cons to saving the L5-S1 motion segment in a long scoliosis fusion construct. Spine (Phila Pa 1976). 2003;28(20):S234-42.

6. DeWald CJ, Stanley T. Instrumentation-related complications of multilevel fusions for adult spinal deformity patients over age 65: surgical considerations and treatment options in patients with poor bone quality. Spine (Phila Pa 1976). 2006:31(19 Suppl):S144-51.

7. Bradford DS, Tay BK, Hu SS. Adult scoliosis: surgical indications, operative management, complications, and outcomes. Spine (Phila Pa 1976). 1999;24(24):2617-29.

8. Hu SS. Internal fixation in the osteoporotic spine. Spine (Phila Pa 1976). 1997;22(24 Suppl):43S-48S

9. Wang $Y$, Zheng G, Zhang X, Zhang Y, Xiao S, Wang Z. Temporary use of shape memory spinal rod in the treatment of scoliosis. Eur Spine J. 2011;20(1):118-22.

10. Di Silvestre M, Lolli F, Greggi T, Vommaro F, Baioni A. Adult's degenerative scoliosis: midterm results of dynamic stabilization without fusion in elderly patients-is it effective? Adv Orthop. 2013;2013:365059. 